\title{
Predicting Available Water Content Using Pedotransfer Functions of Sandy
} Soils in Libya

Nasr, H. M. ; Y. A. A. Nasr and Wafa M. Baayu

Soil Science Department, Faculty of Agriculture, Cairo University

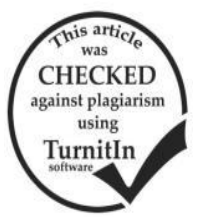

\begin{abstract}
Sandy soils are of a wide occurrence under arid and semiarid regions. Most of Libyan soils are sandy soils. Twenty two soil samples were chosen from the western coastal strip of Libya representing a wide range variation of sand fractions were chosen for this study. Different chemical and physical properties were determined, including particle size distribution, bulk density, retention moisture characteristics and saturated hydraulic conductivity. Available water content was determined using moisture retention data. The available water content obtained were affected mainly by the percentage of silt + clay. These effect was decreased by increasing the diameter of the soil fractions. The empirical equation between the available water content and the silt + clay, can be used in water management practices of the sandy soils.
\end{abstract}

Keywords: Sandy soil, physical, chemical, empirical equation.

\section{INTRODUCTION}

Sandy soils could be characterized by less than $18 \%$ clay and more than $68 \%$ sand in the first $100 \mathrm{~cm}$ of the solum. In the World Reference Base on (WRB) soil classification system (ISS working Group R.B. 1998), sandy soils may occur in the following materials such as alluvium or dunes. Two important characteristics of sandy soil are their coarse texture and high rate of hydraulic conductivity. These characteristics control the determination of the type of farm irrigation system and the amount of water necessary for the irrigation.

The high permeability and low water storage capacity make it very difficult to apply the correct amounts of water. Irrigation of sandy soil may lead to water wastage by deep percolation and low irrigation efficiencies of less than 50 percent. Such properties require the application of special soil and water management practices and adherence to certain cropping patterns to render the utilization of sandy soils more economic.

The term "Pedotransfer functions" was used by Bouma (1989) to describe the quantitative relations between soil characteristics and other characteristics that are more readily available. In other words pedotransfer functions $\left(\mathrm{PTF}_{\mathrm{s}}\right)$ is a term given to the relation between basic physical properties of soil (texture, structure, $\mathrm{CaCO}_{3} \ldots$ ) and other properties that important to the soil management.

The main objectives of this study are:

i) Studying the main properties of the sandy soils of Libya.

ii) Studying the impact of different soil fractions on available water.

iii) Identifying the best empirical equation for predicting available water for sandy soil.

\section{MATERIALS AND METHODS}

Twenty two soil samples were chosen to represent the sandy soil of Libya. The collected samples were subjected to the particle size analysis as described by Gee and Bander (1986). The attained water content percentage at each pressure was determined using the pressure Cooker and Membrane (Klute, 1986). The soil moisture constants, i.e., field capacity (FC), wilting percentage (WP) and the available water capacity were determined on volume base, according to Massoud et al., (1971) and Talha et al., (1986). The saturated hydraulic conductivity $\left(\mathrm{K}_{\mathrm{s}}\right)$ was determined with the constant head method at laboratory (Klute and Drieksen, 1986). The total $\mathrm{CaCO}_{3}$ content was determined gasiometerically as cited by Nelson (1982). Chemical characteristics of the studied soil samples were determined according to the standard methods (black, 1965).

\section{RESULTS AND DISCUSSION}

The studied soil samples are slightly saline where the EC values varied from 0.2 and $1.6 \mathrm{dSm}-1$. Sodium was the predominant cation in all the studied soil samples followed by calcium and magnesium. On the other hand, chloride was the dominant anions followed by sulphates and bicarbonate. These soils ranged between slightly and moderately alkaline (soil $\mathrm{pH}$ ranged from 7.5 to 8.0). Calcium carbonate content ranges from 1.9 to $23.3 \%$. Soils also have lower content of soil organic matter ranged 0.1 to $0.3 \%$, (Table 1 ).

In the dominantly coarse-textured soils mechanical composition of the various soil samples ranged from 63.7 to $96.3 \%$ coarse sand 1.7 to 40.5 fine sand and 2.1 to 23.8 silt + clay.

The bulk density ranged from 1.4 to $1.6 \mathrm{~g} / \mathrm{cc}$ and decreased with decreasing particle size (Table 2).

Table 3 gives the moisture content expressed in percent by weight for each sand separate. The data illustrate that the percentage of moisture was increased and the suction required to drain the pores in the sand separates increased with decreasing particle diameter.

The data show that the amount of soil moisture retained at equal suctions differs from one sand separate to another. The separate with a particle diameter larger than $0.5 \mathrm{~mm}$ released most of its water at a soil water suction range from $0-0.1$ atm., but the separate 1.0 $0.5 \mathrm{~mm}$ retained $4 \%$ of its available moisture at a range of 0.1 to $0.33 \mathrm{~atm}$. The separate 0.25 to 0.125 needed higher suction to release its water ( 0.33 to $1.0 \mathrm{~atm}$.). 
In the separate with a particle diameter smaller than $0.125 \mathrm{~mm}$ no significant amount of water was released below 1 atm., and most of the moisture was retained in the range between 1.0 and $3.0 \mathrm{~atm}$.

The data in Table 4 show that the calculated available moisture between 0.1 to $15 \mathrm{~atm}$. For the studied soil samples. The maximum available water by weight in the different soil samples varied from 2.1 to $14.2 \%$. The soil samples with high percent of silt + clay exhibited a high water holding capacity and higher available moisture compared to those composed of high percent of sand (especially coarse sand).

Table 1:Chemical composition of studied soils

\begin{tabular}{|c|c|c|c|c|c|c|c|c|c|c|c|}
\hline \multirow{2}{*}{ No. } & \multirow{2}{*}{$\begin{array}{c}\text { pH } \\
(1: 2.5)\end{array}$} & \multirow{2}{*}{$\begin{array}{c}\text { O.M } \\
\%\end{array}$} & \multirow{2}{*}{$\begin{array}{c}\mathrm{CaCO}_{3} \\
\%\end{array}$} & \multirow{2}{*}{$\begin{array}{c}\text { EC (1:2.5) } \\
\text { dS/m } \\
\end{array}$} & \multicolumn{7}{|c|}{ Ions species (meq/L) } \\
\hline & & & & & $\mathrm{HCO}_{3}^{-}$ & $\mathrm{Cl}^{-}$ & $\mathrm{SO}_{4}^{--}$ & $\mathrm{Ca}^{++}$ & $\mathrm{Mg}^{++}$ & $\mathrm{Na}^{+}$ & $\mathbf{K}^{+}$ \\
\hline 1 & 7.3 & 0.2 & 3.1 & 1.4 & 3.3 & 9.9 & 0.5 & 4.3 & 3.5 & 5.6 & 0.3 \\
\hline 2 & 7.4 & 0.1 & 3.7 & 0.7 & 2.9 & 5.0 & 0.2 & 2.6 & 1.8 & 3.5 & 0.2 \\
\hline 3 & 7.4 & 0.1 & 3.1 & 1.1 & 1.5 & 9.6 & 0.1 & 4.2 & 2.5 & 4.3 & 0.2 \\
\hline 4 & 7.8 & 0.2 & 11.7 & 2.4 & 4.3 & 18.1 & 4.5 & 8.6 & 4.8 & 13.2 & 0.3 \\
\hline 5 & 7.3 & 0.4 & 12.5 & 2.6 & 5.2 & 18.1 & 2.7 & 8.6 & 3.8 & 13.2 & 0.4 \\
\hline 6 & 7.2 & 0.3 & 14.6 & 1.6 & 3.5 & 11.6 & 2.7 & 5.2 & 2.8 & 9.5 & 0.3 \\
\hline 7 & 7.6 & 0.1 & 8.1 & 1.8 & 3.0 & 12.2 & 4.3 & 4.1 & 3.2 & 12.3 & 0.2 \\
\hline 8 & 7.4 & 0.1 & 10.1 & 1.4 & 3.3 & 9.6 & 1.1 & 4.3 & 2.6 & 6.8 & 0.3 \\
\hline 9 & 7.4 & 0.2 & 13.5 & 2.7 & 4.1 & 13.5 & 9.8 & 5.7 & 4.8 & 16.5 & 0.4 \\
\hline 10 & 7.5 & 0.1 & 15.4 & 3.0 & 3.3 & 18.6 & 8.2 & 7.8 & 6.3 & 15.6 & 0.4 \\
\hline 11 & 7.3 & 0.1 & 1.6 & 2.7 & 5.2 & 17.5 & 5.2 & 6.1 & 7.2 & 14.2 & 0.4 \\
\hline 12 & 7.8 & 0.1 & 1.1 & 1.7 & 5.5 & 15.3 & 0.6 & 5.4 & 4.4 & 11.3 & 0.3 \\
\hline 13 & 7.6 & 0.2 & 3.2 & 1.2 & 2.9 & 6.1 & 3.3 & 3.1 & 1.7 & 7.3 & 0.2 \\
\hline 14 & 7.8 & 0.1 & 1.6 & 2.6 & 2.9 & 18.0 & 6.7 & 6.6 & 4.9 & 15.8 & 0.3 \\
\hline 15 & 7.6 & 0.1 & 3.3 & 2.6 & 4.0 & 15.5 & 7.0 & 5.5 & 3.8 & 17.0 & 0.2 \\
\hline 16 & 7.8 & 0.1 & 1.8 & 1.6 & 3.5 & 9.8 & 2.9 & 3.1 & 2.5 & 10.4 & 0.2 \\
\hline 17 & 7.4 & 0.2 & 5.3 & 1.9 & 3.2 & 12.4 & 3.3 & 4.2 & 2.1 & 12.3 & 0.3 \\
\hline 18 & 7.2 & 0.1 & 2.0 & 1.4 & 2.2 & 9.9 & 2.2 & 5.9 & 0.5 & 7.7 & 0.2 \\
\hline 19 & 7.5 & 0.1 & 2.2 & 1.6 & 2.8 & 8.3 & 5.7 & 2.8 & 3.0 & 10.8 & 0.2 \\
\hline 20 & 7.9 & 0.1 & 3.2 & 1.3 & 2.6 & 7.3 & 2.1 & 2.3 & 1.1 & 8.4 & 0.2 \\
\hline 21 & 7.8 & 0.1 & 3.1 & 1.5 & 3.9 & 9.9 & 2.8 & 5.3 & 3.7 & 7.3 & 0.3 \\
\hline 22 & 7.7 & 0.1 & 4.2 & 1.7 & 4.2 & 12.8 & 3.7 & 4.4 & 5.3 & 10.8 & 0.2 \\
\hline
\end{tabular}

Table 2: Dry sieve of the investigated soil sites in Tripoli

\begin{tabular}{|c|c|c|c|c|c|c|c|}
\hline \multirow[b]{2}{*}{ Depth (cm) } & \multicolumn{6}{|c|}{$\begin{array}{ll}\text { Soil Fractions \% } \\
\end{array}$} & \multirow[b]{2}{*}{$\begin{array}{c}\text { Texture } \\
\text { class }\end{array}$} \\
\hline & $\begin{array}{c}\text { V.C.S } \\
2-1 \mathrm{~mm}\end{array}$ & $\begin{array}{c}\text { C.S } \\
1-0.5 \mathrm{~mm}\end{array}$ & $\begin{array}{c}\text { M.S } \\
0.5-0.25 \mathrm{~mm}\end{array}$ & $\begin{array}{c}\text { F.S } \\
0.25-0.125 \mathrm{~mm}\end{array}$ & $\begin{array}{c}\text { V.F.S } \\
0.125-0.06 \mathrm{~mm}\end{array}$ & $\begin{array}{l}\text { Silt + Clay } \\
>0.06 \mathrm{~mm}\end{array}$ & \\
\hline 1 & 1.7 & 63.6 & 5.7 & 12.7 & 6.6 & 9.7 & Sandy \\
\hline 2 & 1.0 & 72.7 & 3.7 & 10.4 & 4.3 & 7.8 & Sandy \\
\hline 3 & 1.5 & 74.3 & 4.1 & 10.8 & 4.8 & 4.4 & Sandy \\
\hline 4 & 0.5 & 31.4 & 5.1 & 25.8 & 13.3 & 23.8 & Sandy \\
\hline 5 & 1.7 & 82.6 & 4.2 & 4.1 & 3.4 & 3.6 & Sandy \\
\hline 6 & 0.6 & 65.1 & 4.4 & 9.2 & 6.1 & 14.5 & Sandy \\
\hline 7 & 0.5 & 56.2 & 7.6 & 14.3 & 5.7 & 15.7 & Sandy \\
\hline 8 & 0.5 & 40.5 & 6.3 & 26.8 & 13.7 & 12.2 & Sandy \\
\hline 9 & 0.6 & 64.4 & 7.1 & 11.1 & 5.8 & 10.9 & Sandy \\
\hline 10 & 0.5 & 61.5 & 5.1 & 10.4 & 5.1 & 17.3 & Sandy \\
\hline 11 & 32.3 & 49.8 & 8.8 & 3.7 & 0.8 & 4.6 & Sandy \\
\hline 12 & 30.6 & 27.9 & 5.2 & 5.4 & 1.2 & 4.5 & Sandy \\
\hline 13 & 38.6 & 33.9 & 6.2 & 6.3 & 1.5 & 13.6 & Sandy \\
\hline 14 & 18.6 & 43.2 & 9.6 & 3.7 & 0.6 & 24.3 & Sandy \\
\hline 15 & 41.9 & 39.9 & 6.9 & 3.5 & 0.8 & 6.8 & Sandy \\
\hline 16 & 35.2 & 39.8 & 9.2 & 5.6 & 1.5 & 8.8 & Sandy \\
\hline 17 & 26.3 & 50.7 & 4.7 & 3.6 & 1.3 & 13.5 & Sandy \\
\hline 18 & 56.5 & 37.8 & 2.0 & 1.3 & 0.4 & 2.1 & Sandy \\
\hline 19 & 23.5 & 63.9 & 6.9 & 1.6 & 0.2 & 3.8 & Sandy \\
\hline 20 & 48.5 & 28.6 & 4.8 & 2.4 & 0.5 & 15.1 & Sandy \\
\hline 21 & 46.7 & 36.3 & 6.1 & 2.4 & 0.4 & 8.3 & Sandy \\
\hline 22 & 49.7 & 21.2 & 3.2 & 1.6 & 1.4 & 22.9 & Sandy \\
\hline
\end{tabular}


Table 3: Percent moisture by weight at various soil water suction in sand separates

\begin{tabular}{lccccccc}
\hline & \multicolumn{9}{c}{ Soil water suction atm. } \\
Particle size mm.d. & $\mathbf{0}$ & $\mathbf{0 . 1}$ & $\mathbf{0 . 3 3}$ & $\mathbf{1 . 0}$ & $\mathbf{3 . 0}$ & $\mathbf{6 . 0}$ & $\mathbf{1 5 . 0}$ \\
& & \multicolumn{7}{c}{ Percent } & moisture by weight & & \\
\hline $2.00-1.00$ & 25.4 & 5.1 & 1.9 & 1.4 & 1.0 & 0.5 & 0.3 \\
$1-0.50$ & 27.9 & 9.7 & 2.1 & 1.9 & 1.4 & 0.9 & 0.6 \\
$0.50-0.25$ & 30.4 & 23.8 & 2.8 & 2.2 & 1.8 & 1.3 & 0.9 \\
$0.25-0.125$ & 31.6 & 27.4 & 5.3 & 3.8 & 2.9 & 2.1 & 1.2 \\
$0.125-0.05$ & 33.2 & 30.1 & 18.5 & 12.4 & 5.6 & 3.4 & 2.5 \\
Les than 0.05 & 35.6 & 32.7 & 30.6 & 20.1 & 9.4 & 4.8 & 3.1 \\
\hline
\end{tabular}

Table 4:The moisture constants (\% weight) the hydraulic conductivity of the studied soils

\begin{tabular}{|c|c|c|c|c|c|}
\hline No. & $\begin{array}{c}\text { F.C. } \\
\%\end{array}$ & $\begin{array}{c}\text { W.P. } \\
\%\end{array}$ & $\begin{array}{c}\text { AWC } \\
\%\end{array}$ & $\begin{array}{c}\mathrm{Ks} \\
\mathrm{Cm} / \mathrm{h}\end{array}$ & Class of Ks \\
\hline 1 & 6.3 & 1.4 & 4.9 & 10.9 & Slight quickly \\
\hline 2 & 5.3 & 1.2 & 4.1 & 11.5 & Slight quickly \\
\hline 3 & 4.6 & 1.1 & 3.5 & 12.3 & Slight quickly \\
\hline 4 & 13.4 & 3.2 & 10.2 & 4.3 & Moderately \\
\hline 5 & 4 & 1.1 & 2.9 & 12.5 & Slight quickly \\
\hline 6 & 8.4 & 2.5 & 5.9 & 7.8 & Slight quickly \\
\hline 7 & 9.2 & 3 & 6.2 & 8.1 & Slight quickly \\
\hline 8 & 9.1 & 2.2 & 6.9 & 8.5 & Slight quickly \\
\hline 9 & 6.6 & 1.5 & 5.1 & 7 & Slight quickly \\
\hline 10 & 12.7 & 3.1 & 9.6 & 6.1 & Slight quickly \\
\hline 11 & 3.8 & 1 & 2.8 & 14.2 & Slight quickly \\
\hline 12 & 3.7 & 0.9 & 2.8 & 12.2 & Slight quickly \\
\hline 13 & 8.9 & 2 & 6.9 & 10.2 & Slight quickly \\
\hline 14 & 12.6 & 2.9 & 9.7 & 4.3 & Moderately \\
\hline 15 & 5.3 & 1.2 & 4.1 & 9.4 & Slight quickly \\
\hline 16 & 5.2 & 1.5 & 3.7 & 10.5 & Slight quickly \\
\hline 17 & 7.5 & 1.9 & 5.6 & 7.9 & Slight quickly \\
\hline 18 & 2.8 & 0.7 & 2.1 & 12.8 & Quickly \\
\hline 19 & 3.1 & 0.7 & 2.4 & 12.5 & Slight quickly \\
\hline 20 & 8.5 & 1.8 & 6.7 & 7.4 & Slight quickly \\
\hline 21 & 4.8 & 1.3 & 3.5 & 8.3 & Slight quickly \\
\hline 22 & 12.1 & 3.2 & 8.9 & 4.5 & Moderately \\
\hline
\end{tabular}

Fig. 1 to 3 show the relationship between the available water percentage and the percentage of particle less than $0.06 \mathrm{~mm}$, particles less than $0.125 \mathrm{~mm}$ and particles less than $0.25 \mathrm{~mm}$.

The data revealed that the correlation coefficients (r) between the available water percentage and different soil fraction decrease with increase the diameter of the soil fraction. The data revealed that the main soil properties affecting on the available water percentage in sandy soils were the silt + clay content (particles less than $0.06 \mathrm{~mm}$ ). The following equations reveal the relation between the available water percentage and the different soil fractions.

$$
\begin{aligned}
& \mathrm{y} \%=1.690+0.486 \mathrm{x}_{1} \\
& \mathrm{y} \%=3.372+0.241 \mathrm{x}_{2} \\
& \mathrm{y} \%=3.899+0.138 \mathrm{x}_{3}
\end{aligned}
$$$$
\mathrm{y}=\text { percentage of available water } \%
$$

$\mathrm{x}_{1}=$ percentage of silt + clay (less than $0.05 \mathrm{~mm}$ ) $\mathrm{x}_{2}=$ percentage of very fine sand (less than $0.125 \mathrm{~mm}$ )

$\mathrm{x}_{3}=$ percentage of fine sand (less than $0.25 \mathrm{~mm}$ )

The results of these studies explain the importance of soil texture in determining soil moisture holding capacity, available moisture to plants and irrigation requirement. Also growing plants play an important role in extracting the available water. For this reason, the field capacity should be considered as a soil moisture profile and the growing plant function rather than a property of soil in the root zone or the plough layer

The available moisture of these soils when compared with the mean annual rainfall indicates that the moisture is the most important limiting factor, especially during the dry summer months, for plant establishment and growth. 
Nasr, H. M. et al.

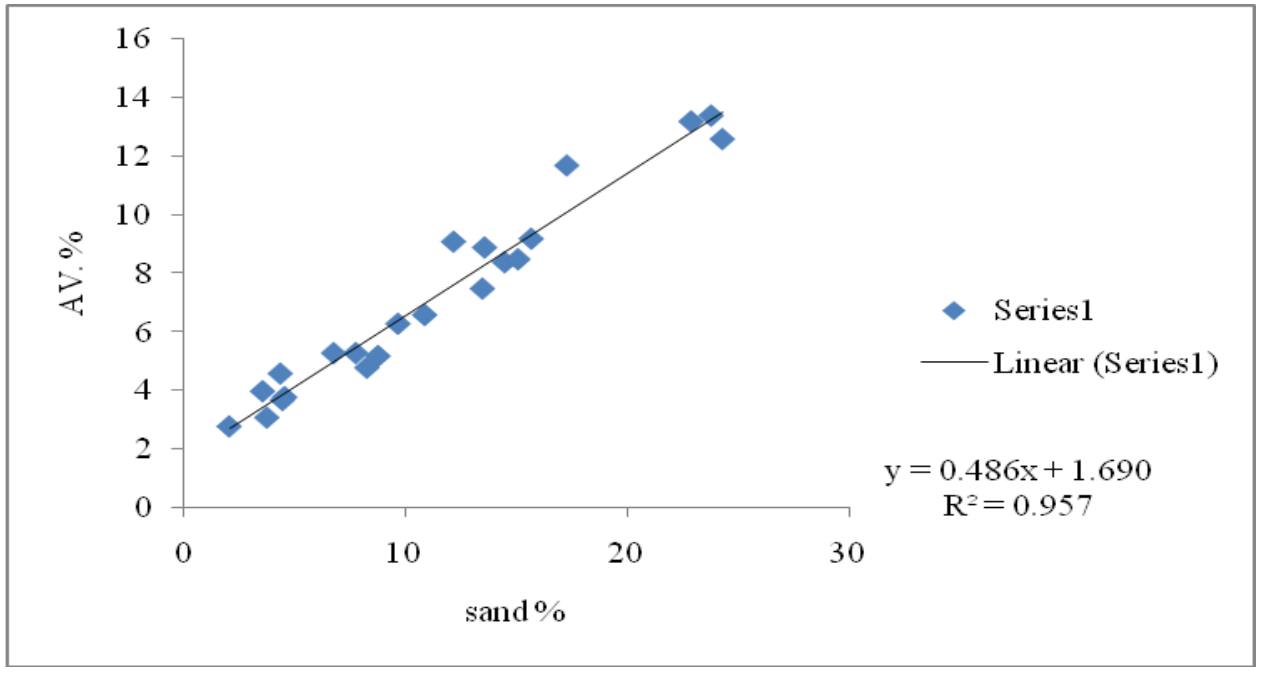

Fig. 1: Relationship between AV.W. Percentage and the percentage of particle size less than $0.06 \mathrm{~mm}$

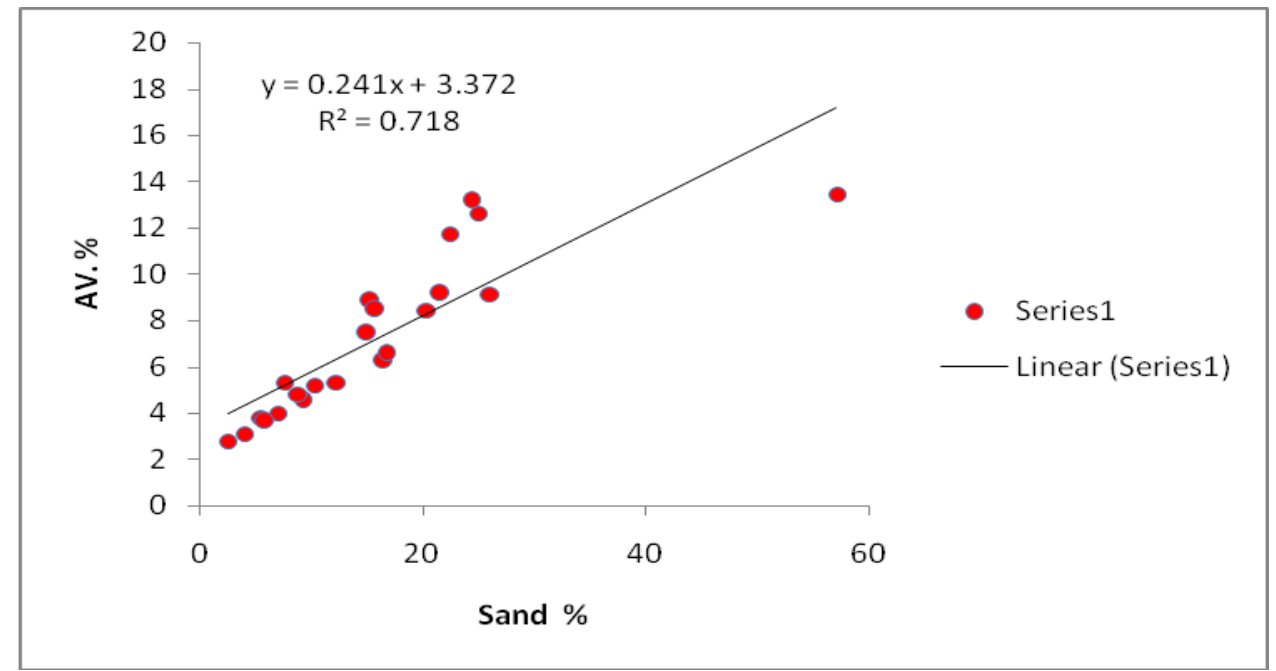

Fig. 2: Relationship between AV.W. Percentage and the percentage of particle size less than $0.125 \mathrm{~mm}$

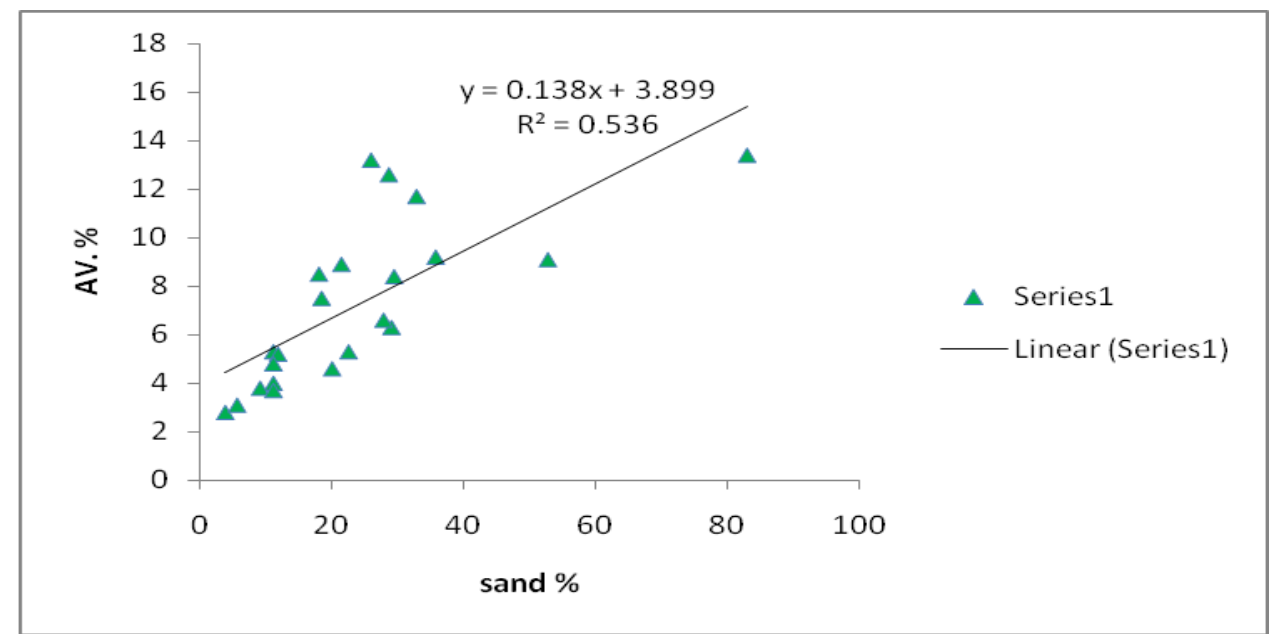

Fig. 3: Relationship between AV.W. Percentage and the percentage of particle size less than $0.25 \mathrm{~mm}$ 


\section{REFERNCES}

Balck, C.A. (1965). "Methods of soil analysis": Part 1, Physical and mineralogical properties including statistics of measurement and sampling: Am. Soc. Agron., Inc. Pub., Madison.

Buma, J. (1989). Using soil survey data for quantitative land evaluation. Adv. Soil Sci. 9, 177.

Gee, G.W. and Bander, J. W. (1986). Particle size analysis In: "Methods of Soil Analysis", Part 1, A. Klute (Ed.), Agronomy No. 9.

ISSS Working Group RB, 1998-World Reference Base for Soil Resources: Introduction (eds. J. A. Deckers, F.O. Nachtergaele \& O.C. Spaargaren). First Ed. International Society of Soil Science (ISSS). ISRIC-FAO-ISSS-ACCO.leuven.

Klute, A. (1986). Water retention: Laboratory method. In: "Methods of soil Analysis", A. Klute (Ed.), Part $1.2^{\text {nd }}$ ed. Agronomy No. 9, pp. 635-662.
Klute A. and Driksen, C. (1986). Hydraulic conductivity and diffusivity: Laboratory methods. In "Methods of Soil Analysis", Part 1., A. Klute (Ed.), pp. 687-734, American Soc. Agronomy, Madison WI. USA.

Massoud, F.I., El-Gably, M.M. and El-Tality, A.F. (1971). Moisture characteristics of the highly calcareous soil of Mariut extension project Egypt. Alex. J. Agric. Res. 19, 351.

Nelson, R.E. (1982). Carbonate and gypsum. In: "Methods of Soil Analysis", Part 2, page (Ed.), pp. 181-197, A5, Agronomy Nomograph No. 9, Madison, Wisconsin.

Talha, M,; Abd El-Samie, A.G. and Ghazy, A. (1986). Soil moisture characteristics of calcareous soils. Egypt. J. Soil Sci. 19, 105.

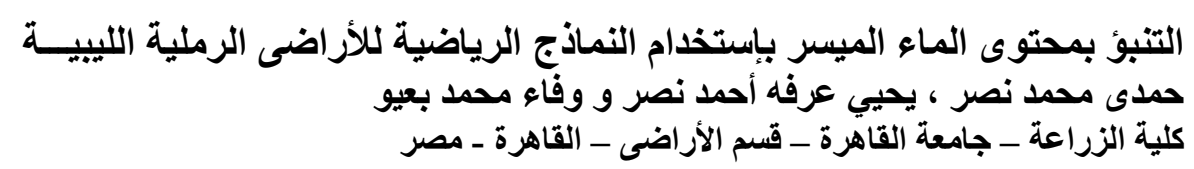

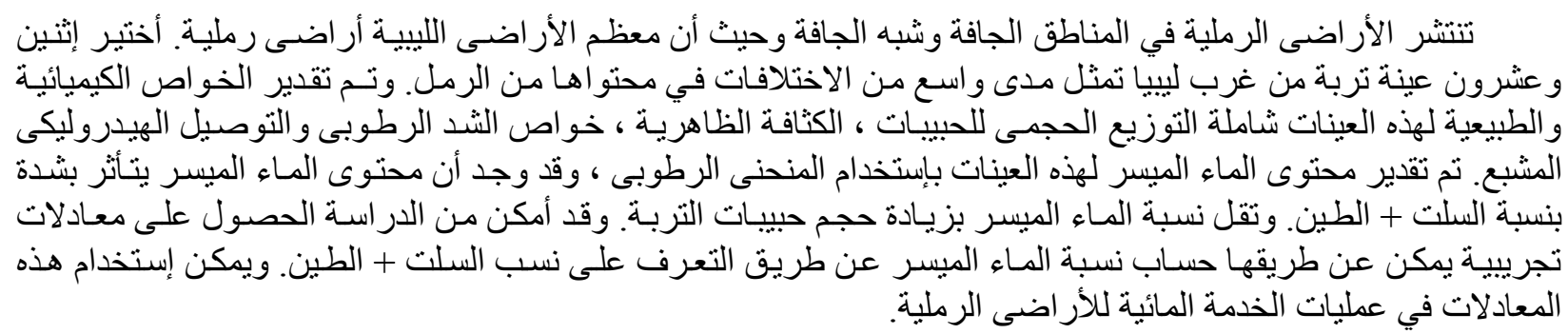

